\title{
Use of Nicarbazin, Salinomycin and Zinc Oxide as Alternative Molting Methods for Commercial Laying Hens
}

http://dx.doi.org/10.1590/1516-635x160225-30

\section{-Author(s)}

Domingues $\mathrm{C} \mathrm{H}$ de $\mathrm{F}$

Sgavioli S'

Praes M F F M'

Castiblanco D M C

Marchizeli PC A

Pereira A $A^{\prime}$

Duarte $\mathrm{K} \mathrm{F}^{\mathrm{I}}$

Junqueira O M

Universidade Estadual Paulista Júlio de Mesquita Filho, Jaboticabal, SP.

\section{ABSTRACT}

An experiment was carried out to evaluate the performance, egg quality and morphometry of the reproductive tract, liver, pancreas and tongue of laying hens submitted to different molting methods. Two hundred and eighty eight 72-week-old Isa brown layers were distributed according to a completely randomized design with six treatments (molting methods) and six replicates of eight birds each. Layers were fed diets containing 3000 ppm zinc oxide, 60 ppm or 120 ppm nicarbazin, $30 \mathrm{ppm}$ or $60 \mathrm{ppm}$ salinomycin, or were submitted to feed fasting. Data were submitted to analysis of variance and means were compared by the test of Tukey at $5 \%$ probability level. Molting methods alternative to feed fasting were effective to induce molting in layer and provided good performance results in the second laying cycle.

\section{INTRODUCTION}

Modern layer strains have high genetic potential for egg production and may produce eggs for more than one laying cycle by inducing molting. Forced molting is defined as a set of management practices to promote stress, inducing birds to stop producing eggs and the partial molting of the feathers (Roland \& Brake, 1982). The objective of forced molting is to rest the reproductive system of layers for some time in order to recover their production capacity and to increase the longevity of layers for further 25 to 30 weeks, as well as to improve egg quality, reducing losses caused by poor eggshell quality (Berry, 2003).

Alternative molting techniques, except for the supply of zinc-rich diets, have shown to be as effective to discontinue egg production as feed restriction. Layers fed diets with nicarbazin reduce egg production and egg weight (Chapman, 1994), as nicarbazin may prevent ovule maturation (Baker et al., 1957). High doses of ionophore antibiotics, such as salinomycin, may cause severe cell function and morphological disorders in poultry (Novilla, 1992), and anorexia is one of the most frequent clinical signs (Schweitzer et al., 1984).

Similarly to mammals, poultry also have taste buds (Kare et al., 1976) and are capable of differentiating the flavor of different chemical solutions, although behavioral effects are not evident (Denbow, 1985). Changes in diet composition, such as drug inclusion and excessive mineral content, could result in changes in the taste buds, and therefore directly influence poultry intake activities (Denbow, 1985).

The objective of the present study was to evaluate molting methods alternative to feed fasting on the performance, egg quality, and morphometrics of the tongue, reproductive tract, liver, and pancreas of commercial layers. 
Domingues CH de F, Sgavioli S, Praes MFFM, Castiblanco DMC, Marchizeli PCA, Pereira AA,

Duarte KF, Junqueira OM
Use of Nicarbazin, Salinomycin and Zinc Oxide as Alternative Molting Methods for Commercial Laying Hens

\section{MATERIALS AND METHODS}

The experimental period included the phases of molting, resting, and second laying cycle (four periods of 28 days each). Hens were selected according to body weight and egg production. In the trial, 288 commercial Isa Brown layers with 72 weeks of age were distributed, according to a completely randomized experimental design into six treatments with six replicates of eight birds each, totaling 36 experimental units.

Feeds supplied during the experimental periods were formulated according to Rostagno (2011), as shown in Table 1. The molting diet contained 16.29\% crude protein, $0.44 \%$ calcium, $0.275 \%$ available phosphorus, and $0.02 \%$ sodium.

The following treatments were applied for 14 days to induce molting: feed fasting and the dietary inclusion of 3000 ppm zinc oxide, 60 or 120 ppm nicarbazin, or 30 or 60 ppm salinomycin.

Table 1 - Ingredients and nutritional composition of the experimental diets.

\begin{tabular}{|c|c|c|c|}
\hline Ingredients (\%) & $\begin{array}{c}\text { Molting } \\
\text { diet }\end{array}$ & $\begin{array}{c}\text { Resting } \\
\text { diet }\end{array}$ & $\begin{array}{l}\text { Lay } \\
\text { diet }\end{array}$ \\
\hline Corn grain & 70.47 & 77.17 & 66.06 \\
\hline Soybean meal (45\%) & 19.50 & 11.70 & 21.80 \\
\hline Wheat midds & 8.00 & 8.00 & - \\
\hline Limestone & 0.35 & 1.40 & 9.20 \\
\hline Dicalcium phosphate & 0.90 & 1.11 & 1.01 \\
\hline Mineral and vitamin supplement* & 0.20 & 0.20 & 0.20 \\
\hline Salt & 0.01 & 0.40 & 0.50 \\
\hline DL-methionine & 0.15 & 0.02 & 0.16 \\
\hline Soybean oil & - & - & 1.07 \\
\hline Variable portion** & 0.42 & - & - \\
\hline Total & 100 & 100 & 100 \\
\hline \multicolumn{4}{|l|}{ Nutritional composition } \\
\hline Metabolizable energy (kcal/kg) & 2.868 & 2.910 & 2.850 \\
\hline Crude protein (\%) & 16.29 & 13.31 & 15.60 \\
\hline Calcium (\%) & 0.440 & 0.870 & 3.850 \\
\hline Available phosphorus (\%) & 0.275 & 0.310 & 0.280 \\
\hline Total phosphorus (\%) & 0.529 & 0.543 & 0.483 \\
\hline Sodium (\%) & 0.020 & 0.170 & 0.210 \\
\hline Total lysine (\%) & 0.762 & 0.562 & 0.764 \\
\hline Digestible lysine (\%) & 0.684 & 0.499 & 0.694 \\
\hline Total methionine (\%) & 0.406 & 0.240 & 0.415 \\
\hline Digestible methionine (\%) & 0.377 & 0.216 & 0.389 \\
\hline Total methionine + cystine (\%) & 0.688 & 0.486 & 0.677 \\
\hline Digestible methionine + cystine (\%) & 0.622 & 0.430 & 0.620 \\
\hline Total threonine (\%) & 0.613 & 0.495 & 0.599 \\
\hline Digestible threonine (\%) & 0.526 & 0.425 & 0.523 \\
\hline Total tryptophan (\%) & 0.186 & 0.143 & 0.181 \\
\hline Digestible tryptophan (\%) & 0.164 & 0.125 & 0.162 \\
\hline
\end{tabular}

*Supplied per kg feed: 8,000 IU vitamin A, 1,800 IU vitamin D3, 12 mg vitamin E, 2 mg vitamin K3, 1 mg vitamin B1, 4 mg vitamin B2, 1 mg vitamin B6, 10 mcg vitamin $\mathrm{B} 12,0.40 \mathrm{mg}$ folic acid, $0.04 \mathrm{mg}$ biotin, $28 \mathrm{mg}$ niacin, $11 \mathrm{mg}$ calcium pantothenate, 6 mg Cu, 0.10 mg Co, 1 mg I, 50 mg Fe, 65 mg Mn, 45 mg Zn, 0.21 mg Se, 500 mg choline chloride 50\%, $1400 \mathrm{mg}$ methionine, $125 \mathrm{mg}$ antioxidant.

Variable portion** The variable portion consisted of finely-ground rice hulls and/or zinc oxide and/or each of the anticoccidial agents.
During molting, the following performance parameters were evaluated: days until laying ceased, feed intake, egg production, body weight lost between 7 and 14 days.

During the resting period, feed intake, egg production, days to return to lay $(50-60 \%$ egg production), days to lay of the first and the tenth egg, body weight recovery, feed conversion ratio ( $\mathrm{kg}$ feed/ dozen eggs), and livability were evaluated.

During the second laying cycle, the following performance parameters were evaluated at the end of each period: feed intake (feed offer minus feed residue), egg production (average number of eggs laid per experimental unit), feed conversion ratio ( $\mathrm{kg}$ of feed per kg of eggs and per dozen eggs produced), average egg weight (total egg weight/number of eggs laid per experimental unit), and egg mass (egg production $\% x$ average egg weight). The following egg quality parameters were evaluated: Haugh units, calculated as $100 \log \left(h+7.57-1.7 W^{0.37}\right)$, where $\mathrm{H}=$ albumen height in $\mathrm{mm}, \mathrm{W}=$ egg weight in g; eggshell percentage and thickness, and egg specific gravity. Egg specific gravity was determined immersing the eggs in graded $\mathrm{NaCl}$ solutions $\left(1.065\right.$ to $1.100 \mathrm{~g} / \mathrm{cm}^{3}$, in 0.005 gradients).

Birds were sacrificed at the end of the molting period and of the resting period. Hens were sacrificed by neck dislocation after feed fasting for eight hours. Birds were previously fasted for eight hours and weighed immediately before sacrifice to allow subsequent calculation of ovary, oviduct, liver, and pancreas weights relative to body weight.

The tongue was removed from caudal region of the mouth cavity, immersed in formalin at 10\% and submitted to morphometric evaluation, which included taste bud counting and measuring their area and diameter in histological slides. Tongue samples were fixed in Bouin solution (saturated solution of picric acid, acetic acid, and formalin) for 24 hours at room temperature. Samples were than rinsed in water to remove excessive fixing solution, immersed in ethanol at $70 \%$, processed according to light microscopy routine methods with the inclusion in histosec. Samples were dehydrated in graded series of ethanol (80\%, 90\%, 95\%, and absolute ethanol (3x), cleared in alcohol xylol solution (1:1) and xylol (3x), embedded in paraffin (3x), and included with histosec (40 minutes for each solution. Semi-serial cross sections $(6 \mu \mathrm{m})$ were cut per sample, which were then deparaffinized and stained with hematoxylin-eosin ( $\mathrm{HE})$, and again dehydrated and cleared for finally mounting the slides with Entellan ${ }^{\circledR}$. 
Domingues CH de F, Sgavioli S, Praes MFFM, Castiblanco DMC, Marchizeli PCA, Pereira AA,

Duarte KF, Junqueira OM

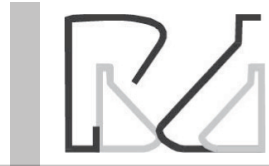

Taste bud number, area, and diameter were determined at 40x magnification using a light microscope $\left(\right.$ Olympus $^{\circledR}$ ), which was coupled to a digital image analyzing system (Leica, Digital Image Processing And Analysis Software For Professional Microscopy- Qwin V3) together with Optimus 4.0 software program.

The obtained data were submitted to analysis of variance using the General Linear Model (GLM) procedure of SAS statistical package (SAS Institute, 2002). Means were compared by the test of Tukey at $5 \%$ probability level.

\section{RESULTS AND DISCUSSION}

The applied treatments significantly influenced the evaluated performance parameters (Table 2).

The feed intake of the hens fed the diet containing 3000 zinc oxide was significantly lower compared to the other treatments $(p<0.05)$. This is consistent with the results of Shippee et al. (1979), who observed that layers fed $1 \%$ zinc as zinc oxide or zinc acetate presented feed intake of 22 and $16 \mathrm{~g} / \mathrm{bird}$, respectively, during the second week of the induced molting period, when hens also presented $0 \%$ egg production. This may due to reduced appetite (Bar et al. 2003) or palatability (Fok, 1989). It was also reported that feed intake may be reduced because zinc cation $\left(\mathrm{Zn}_{2}{ }^{+}\right)$ induces follicle atresia, interrupting egg production (Johnson \& Brake, 1992). Therefore, it is possible that the efficiency of the treatment with the diet with high zinc levels is directly related with feed intake.

Layers fed 60 ppm nicarbazin produced more eggs than those submitted to feed fasting. This result is different from the findings of Park et al. (2004), who
Use of Nicarbazin, Salinomycin and Zinc Oxide as Alternative Molting Methods for Commercial Laying Hens

did not observe any differences in egg production among different induced-molting methods (fasting and dietary inclusion of zinc acetate or zinc propionate).

Layers submitted to feed fasting during the inducedmolting period presented higher weight loss on day 7 compared with those fed 60 ppm nicarbazin, but not with those submitted to the other treatments. On day 14 of induced molting, hens in the feed fasting treatment lost the most body weight during this period and those fed 60 ppm nicarbazin and 3000 ppm zinc oxide lost the least body weight. Body weight loss contributes for molting as it affects reproduction and body fat reserves (Park et al. 2004). According to Alodan \& Mashaly (1999), the regression of the reproductive tract is proportional to body weight loss, which rejuvenates the reproductive tract and reduces body fat, thereby enhancing tissue efficiency.

The fed-fasted hen required less days to cease egg laying compared with those fed the $30 \mathrm{ppm}$ zinc diet, but were not different from those submitted to the other treatments. According to North \& Bell (1990) and Bell (2003), the sooner the hens cease laying eggs, the sooner they will start producing eggs during the resting period, and the peak of egg production in the second cycle occurs sooner.

During the resting period, feed intake significantly increased $(p<0.05)$ when hens were fed 3000 ppm zinc during the molting period relative to those fed $60 \mathrm{ppm}$ nicarbazin, but was not different compared with the other treatments. This is probably due to the low feed intake of the hens fed 3000 ppm zinc oxide during the molting period. On the other hand, Hassanabadi \& Kermanshahi (2007) did not find any reduction in the feed intake of layers fed 20,000 ppm zinc oxide during the molting period.

Table 2 - Average performance parameters obtained during the molting period.

\begin{tabular}{|c|c|c|c|c|c|}
\hline Treatments & $\begin{array}{l}\text { Feed intake } \\
(\mathrm{g} / \mathrm{hen} / \mathrm{d})\end{array}$ & $\begin{array}{c}\text { Egg production } \\
(\%)\end{array}$ & $\begin{array}{c}\text { Body weight loss } \\
\text { Day } 7(\%)\end{array}$ & $\begin{array}{c}\text { Body weight loss } \\
\text { Day } 14(\%)\end{array}$ & Days to lay cessation \\
\hline $\begin{array}{l}\text { Zinc oxide } \\
3000 \text { ppm }\end{array}$ & $38.18 b$ & $15.71 \mathrm{ab}$ & 16.74ab & $18.40 \mathrm{~b}$ & $6.16 a b$ \\
\hline $\begin{array}{l}\text { Nicarbazin } \\
60 \text { ppm }\end{array}$ & $62.39 a$ & $20.46 a$ & $11.68 b$ & $11.68 \mathrm{c}$ & 6.33ab \\
\hline $\begin{array}{l}\text { Nicarbazin } \\
120 \text { ppm }\end{array}$ & $61.90 a$ & 15.90ab & 18.49ab & $13.44 \mathrm{bc}$ & $6.00 a b$ \\
\hline $\begin{array}{l}\text { Salinomycin } \\
30 \text { ppm }\end{array}$ & $58.94 a$ & 19.50ab & 19.62ab & $12.81 \mathrm{bc}$ & $7.50 a$ \\
\hline $\begin{array}{l}\text { Salinomycin } \\
60 \text { ppm }\end{array}$ & $59.60 a$ & $18.23 a b$ & $26.73 a b$ & $14.52 \mathrm{bc}$ & $6.33 a b$ \\
\hline Feed fasting & - & $14.17 \mathrm{~b}$ & $30.34 a$ & $28.93 a$ & $4.00 \mathrm{~b}$ \\
\hline F value & $63.08^{*}$ & $3.64^{\star}$ & $4.71 *$ & $20.39 *$ & $3.11 *$ \\
\hline $\mathrm{CV}^{1}(\%)$ & 5.58 & 18.13 & 21.57 & 21.04 & 26.11 \\
\hline
\end{tabular}

"Significant at $5 \%$ probability level. a,b Means followed by different letters are statistically different. ${ }^{1}$ Coefficient of variation. 
Layers fed 60 and 120 ppm nicarbazin needed fewer days to lay the $1^{\text {st }}$ and $10^{\text {th }}$ egg during the resting period, suggesting a direct relationship between the beginning of lay in the resting period and body weight loss during molting. This was also observed by Sgavioli et al. (2011), who obtained lower body weight loss and shorter interval to lay the first egg during the resting period in layers fed alfalfa to induce molting.

Table 3 - Average performance parameters obtained during the resting period.

\begin{tabular}{|c|c|c|c|c|c|c|c|}
\hline Treatments & $\begin{array}{l}\text { Feed intake } \\
(\mathrm{g} / \mathrm{hen} / \mathrm{d})\end{array}$ & $\begin{array}{l}\text { Egg production } \\
(\% / \text { hen/d })\end{array}$ & $\begin{array}{l}\text { Return to } \\
\text { lay (days) }\end{array}$ & $\begin{array}{l}1^{\text {st }} \text { egg laid } \\
\text { (days) }\end{array}$ & $\begin{array}{l}10^{\text {th }} \text { egg laid } \\
\text { (days) }\end{array}$ & $\begin{array}{l}\text { Feed conversion ratio } \\
\qquad(\mathrm{kg} / \mathrm{dz})\end{array}$ & $\begin{array}{l}\text { Livability } \\
(\%)\end{array}$ \\
\hline $\begin{array}{l}\text { Zinc oxide } \\
3000 \text { ppm }\end{array}$ & $103.80 a$ & 31.42 & 9.16 & $8.16 a b$ & $12.66 \mathrm{ab}$ & 4.22 & 88.19 \\
\hline $\begin{array}{l}\text { Nicarbazin } \\
60 \text { ppm }\end{array}$ & $91.00 b$ & 22.83 & 7.00 & $2.66 c$ & $8.66 c$ & 4.31 & 91.66 \\
\hline $\begin{array}{l}\text { Nicarbazin } \\
120 \text { ppm }\end{array}$ & $99.61 \mathrm{ab}$ & 30.93 & 7.66 & $4.16 c$ & $8.5 c$ & 3.71 & 91.36 \\
\hline $\begin{array}{l}\text { Salinomycin } \\
30 \text { ppm }\end{array}$ & $95.72 \mathrm{ab}$ & 25.90 & 13.66 & $5.00 \mathrm{bc}$ & $10.83 \mathrm{bc}$ & 3.44 & 91.36 \\
\hline $\begin{array}{l}\text { Salinomycin } \\
60 \text { ppm }\end{array}$ & $94.17 a b$ & 23.05 & 11.33 & $5.33 \mathrm{bc}$ & $10.33 b c$ & 5.16 & 91.36 \\
\hline Feed fasting & $97.55 a b$ & 25.74 & 16.00 & $10.66 a$ & $15.33 a$ & 4.84 & 93.75 \\
\hline F value & $2.48^{*}$ & $1.28^{\mathrm{ns}}$ & $2.41^{\mathrm{ns}}$ & $15.62 *$ & $17.42^{*}$ & $1.73^{\text {ns }}$ & $0.31^{\mathrm{ns}}$ \\
\hline$C V^{1}(\%)$ & 7.13 & 30.40 & 51.66 & 30.07 & 13.48 & 26.34 & 8.58 \\
\hline
\end{tabular}

ns $=$ not significant *Significant at $5 \%$ probability level. a,b Means followed by different letters are statistically different. ${ }^{1}$ Coefficient of variation.

During the second laying cycle, performance was significant influenced $(p<0.05)$ by the treatments (Table 4).

Layers fed $30 \mathrm{ppm}$ salinomycin laid significantly lighter eggs compared to those submitted to feed fasting. However, egg weight was not different among treatments with zinc oxide, nicarbazin at both concentrations, and $60 \mathrm{ppm}$ salinomycin. This result may be explained by the greater body weight loss of those hens during molting, which directly affects reproductive tract rejuvenation and fat reserve loss (Alodan \& Mashaly, 1999).

There was no influence of treatments on the other evaluated parameters ( $p>0.05$ )

Although fed-fasted layers laid heavier eggs during the second laying cycle (Table 4), no changes in eggshell quality were observed.

Table 4 - Average performance parameters of layers during the second laying cycle.

\begin{tabular}{|c|c|c|c|c|c|c|}
\hline Treatments & $\begin{array}{l}\text { Feed intake } \\
\text { (g/hen/d) }\end{array}$ & Egg production (\%) & $\begin{array}{l}\text { Feed conversion } \\
\text { ratio }(\mathrm{kg} / \mathrm{dz})\end{array}$ & $\begin{array}{l}\text { Feed conversion } \\
\text { ratio }(\mathrm{kg} / \mathrm{kg})\end{array}$ & Egg weight (g) & Egg mass (g/day) \\
\hline $\begin{array}{l}\text { Zinc oxide } \\
3000 \text { ppm }\end{array}$ & 88.81 & 54.17 & 2.02 & 2.71 & $63.89 \mathrm{ab}$ & 36.19 \\
\hline $\begin{array}{l}\text { Nicarbazin } \\
60 \text { ppm }\end{array}$ & 89.56 & 54.14 & 2.03 & 2.70 & 64.19ab & 36.20 \\
\hline $\begin{array}{l}\text { Nicarbazin } \\
120 \text { ppm }\end{array}$ & 92.03 & 53.50 & 2.03 & 2.61 & 66.09ab & 34.50 \\
\hline $\begin{array}{l}\text { Salinomycin } \\
30 \text { ppm }\end{array}$ & 93.17 & 54.10 & 2.02 & 2.99 & $62.52 b$ & 33.85 \\
\hline $\begin{array}{l}\text { Salinomycin } \\
60 \text { ppm }\end{array}$ & 90.45 & 59.67 & 1.91 & 2.74 & $64.95 a b$ & 36.15 \\
\hline Feed fasting & 101.44 & 61.71 & 2.01 & 2.47 & $67.95 a$ & 38.47 \\
\hline F value & $0.82^{\text {ns }}$ & $0.26 \mathrm{NS}$ & 0.83 NS & $1.92 \mathrm{NS}$ & $4.75^{*}$ & $0.61 \mathrm{NS}$ \\
\hline $\mathrm{CV}^{1}(\%)$ & 10.1 & 9.04 & 6.90 & 7.81 & 2.17 & 9.95 \\
\hline
\end{tabular}

ns $=$ not significant ${ }^{*}$ Significant at $5 \%$ probability level. a,b Means followed by different letters are statistically different. ${ }^{1}$ Coefficient of variation. 
Domingues CH de F, Sgavioli S, Praes MFFM, Castiblanco DMC, Marchizeli PCA, Pereira AA,

Duarte KF, Junqueira OM
Use of Nicarbazin, Salinomycin and Zinc Oxide as Alternative Molting Methods for Commercial Laying Hens

The lack of effect of induced-molting methods on relative weight of the oviduct $(p<0.05)$ was also observed by Araújo et al. (2007), who evaluated different molting methods (California method, diet with high zinc, low calcium or low sodium diets) and did not detect any influence of the treatments on this parameter.

On the other hand, Sgavioli et al. (2013) evaluated different molting methods (dietary inclusion of 90, 70, or $50 \%$ alfalfa, of 2800 ppm zinc oxide or feed fasting) and obtained higher oviduct weights when layers were fed diets including alfalfa relative to zinc oxide.

Layers submitted to feed fasting presented lower liver relative weight $(1.36 \%)$ compared with those fed 120 ppm salinomycin, but it was not statistically different relative to the other treatments.

Pancreas relative weight was statistically lower in feed-fasted layers compared with those fed 30 ppm salinomycin.

The results of the present experiment are consistent with the finding of Domingues et al. (2012), who used 3000 ppm zinc oxide to induce molting, and obtained similar ovary, oviduct, liver, and pancreas weight values after molting.

After the period of resting, no differences ( $p>0.05)$ were observed in the relative weight of the evaluated organs (Table 7).

Table 7 - Average relative organ weights of layers sacrificed at the end of the resting period.

\begin{tabular}{lcccc}
\hline Treatments & $\begin{array}{c}\text { Ovary } \\
(\%)\end{array}$ & $\begin{array}{c}\text { Oviduct } \\
(\%)\end{array}$ & $\begin{array}{c}\text { Liver } \\
(\%)\end{array}$ & $\begin{array}{c}\text { Pancreas } \\
(\%)\end{array}$ \\
\hline Zinc oxide $3000 \mathrm{ppm}$ & 1.79 & 2.56 & 2.43 & 0.19 \\
Nicarbazin $60 \mathrm{ppm}$ & 2.48 & 3.34 & 2.34 & 0.19 \\
Nicarbazin $120 \mathrm{ppm}$ & 2.29 & 3.67 & 2.59 & 0.19 \\
Salinomycin $30 \mathrm{ppm}$ & 1.91 & 3.18 & 2.51 & 0.17 \\
Salinomycin $60 \mathrm{ppm}$ & 2.17 & 3.44 & 2.55 & 0.17 \\
Fasting & 1.97 & 3.02 & 2.41 & 0.18 \\
\hline F value & $0.69^{\mathrm{ns}}$ & $1.34^{\mathrm{ns}}$ & $0.24^{\mathrm{ns}}$ & $0.37^{\mathrm{ns}}$ \\
\hline CV1 (\%) & 28.47 & 18.99 & 15.36 & 17.80 \\
\hline
\end{tabular}

ns $=$ not significant. ${ }^{1}$ Coefficient of variation

The results indicate that, during resting, layers submitted to the different molting treatments presented similar organ recovery. Therefore, the effects observed during molting did not persist after resting.

When tongue morphometric parameters were evaluated, only taste bud numbers were significantly influenced by the treatments (Table 8). 
Domingues $\mathrm{CH}$ de F, Sgavioli S, Praes MFFM, Castiblanco DMC, Marchizeli PCA, Pereira AA, Duarte KF, Junqueira OM

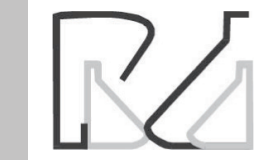

Table 8 - Average values of tongue morphometric parameters evaluated after molting.

\begin{tabular}{lccc}
\hline Treatment & Area $(\mu \mathrm{m})$ & $\begin{array}{c}\text { Diameter } \\
\left(\mu \mathrm{m}^{2}\right)\end{array}$ & Taste bud number \\
\hline Zinc oxide 3000 ppm & 1716.7 & 51.99 & $5.35 \mathrm{~b}$ \\
Nicarbazin 60 ppm & 2231.9 & 48.43 & $4.90 \mathrm{~b}$ \\
Nicarbazin $120 \mathrm{ppm}$ & 1716.7 & 45.95 & $5.60 \mathrm{~b}$ \\
Salinomycin 30 ppm & 2231.9 & 51.65 & $4.35 \mathrm{~b}$ \\
Salinomycin 60 ppm & 1972.1 & 48.65 & $5.10 \mathrm{~b}$ \\
Fasting & 820.07 & 31.48 & $8.00 \mathrm{a}$ \\
\hline F value & $18.01^{\mathrm{ns}}$ & $21.37^{\mathrm{ns}}$ & $5.02^{*}$ \\
\hline $\mathrm{CV}^{1}(\%)$ & 37.84 & 19.39 & 44.38 \\
\hline
\end{tabular}

ns $=$ not significant * Significant at 5\% probability level. a,b Means followed by different letters are statistically different. ${ }^{1}$ Coefficient of variation.

Layers fed diets containing zinc oxide, nicarbazin and salinomycin presented less taste buds compared to those submitted to feed fasting during molting.

According to Gonzáles (2002), feed palatability is perceived by the taste buds, which act as sensors and may be affected by chemical substances. Shosberg et al. (1986) mentioned that those agents, due to their toxicity when added at high levels, may reduce the number of taste buds, and consequently, feed palatability.

\section{CONCLUSIONS}

Based on the results obtained in the present study, it was concluded that methods alternative to feed fasting were efficient to induce feather molting in layers. Relative to the main performance parameters, only the diet with $30 \mathrm{ppm}$ salinomycin caused lower egg weight. Therefore, it may be inferred that methods other than feed fasting can be safely applied to induce molting in layers, promoting adequate performance in the second laying cycle.

\section{REFERENCES}

Alodan MA, Mashaly MM. Effect of induced molting in laying hens on production and immune parameters. Poultry Science 1999;78:171-177.

Araújo CSS, Artoni SMB, Araújo LF, Junqueira OM, Barbosa LCGS, Lima CG. Morfometria do oviduto de poedeiras comerciais semipesadas submetidas a diferentes métodos de muda. Ciência Rural 2007;37(1):241-246

Baker M, Brake J, Mc Daniel GR. The relationship between body weight loss during an induced molt and postmolt egg production, egg weight, and shell quality in caged layers. Poultry Science 1983; 62:409-413.

Bar A, Razaphkovsky V, Shinder D, Vax E. Alternative procedures for molt induction: Practical aspects. Poultry Science 2003;82:543-550.

Bell DD. Historical and current molting practices in the U.S. table egg industry. Poultry Science, 2003;82: 965-970.

Berry WD. The physiology of induced molting. Poultry Science, 2003:82:971-980
Use of Nicarbazin, Salinomycin and Zinc Oxide as Alternative Molting Methods for Commercial Laying

Hens

Brake J. Recents advances in induced molting. Poultry Science 1993;72:929931

Chapman HD. A review of the biological activity of the anticoccidial drug nicarbazin and its application for the control of coccidiosis in poultry. Poultry Science Review, 1994;3:231-243.

Denbow DM. Food intake control in birds. Neuroscience \& Biobehavioral Reviews 1985; 9:223-232.

Domingues CHF, Sgavioli S, Praes MFFM, Duarte KF, Castiblanco DMC, Santos ET, Alva J CR, Junqueira O M. Lysine and methionine + cystine for laying hens during the post-molting phase. Brazilian Journal of Poultry Science 2012;14(3):187-192.

Fox MRS. Zinc excess. In: Mills CF, editor. Zinc in human biology. New York: Springer-Verlag; 1989. p. 365-370.

Gonzales E. Ingestão de alimentos: mecanismos regulatórios. In: Macari M, Furlan RL, Gonzáles E, editor. Fisiologia aviária aplicada a frangos de corte. Jaboticabal: Funep; 2002. p.187-199.

Hassanabadi A, Kermanshahi $H$. Effect of force molting on postmolt performance of laying hens. Journal of Poultry Science 2007;6:630-633.

Johnson AL, Brake J. Zinc-induced molt: Evidence for a direct inhibitory effect in granulose cell steroidogenesis. Poultry Science 1992;71:161-167.

Kare MR, Rogers JG. Sense organs. In: Sturkie PD, editor. Avian physiology. New York: Springer Verlag; 1976.

McCornicky CC, Cunningham DL. Performance and physiological profiles of high dietary zinc and fasting as methods of inducing a forced rest: a direct comparision. Poultry Science 1987;66:1007-1013.

North MO, Bell DD. Commercial Chicken Production manual. $4^{\text {th }}$ ed. New York: Chapman and Hall; 1990. p.433-452.

Novilla MN. The veterinary importance of toxic syndrome induced by ionophores. Veterinary and Human Toxicology 1992;34:66-70.

Park SY, Birhold SG, Kubena LF, Nisbet, DJ, Ricke, SC. Effects of high zinc diets using zinc propionate on molt induction, organs and postmolt egg production and quality in laying hens. Poultry Science 2004;83:24-33.

Roland DA, Brake JH. Influence of premolt production on postmolt performance with explanation for improvement in egg production due to force molting. Poultry Science 1982; 61(12):2473-2481.

Rostagno HS, Albino LFT, Donzele JL. Tabelas brasileiras para aves e suínos: Composição de alimentos e exigências nutricionais. $3^{a}$ ed. Viçosa: Universidade Federal de Viçosa; 2011. 120p

SAS Institute. SAS user's guide:statistics. Cary; 2002. 466p.

Shippee RL, Stake PE, Koehn U, Lambert JL, Simmons RW. High dietary zinc or magnesuim as forced-resting agensts for laying hens. Poultry Science 1979:58:949-954.

Shlosberg A, Perl S, Yakobson B, Klopfer U, Egyed MN, Nobel TA. 1986. Chronic case of probable monensin toxicosis in cattle. Veterinary and Human Toxicology. 1986;28:230-233

Sgavioli S, Filardi RS, Praes MFFM, Assuena V, Pileggi J, Andrade PC, Boleli $I C$, Junqueira OM. Performance of layers submitted to different forcedmolting methods and different temperatures. Brazilian Journal of Poultry science, $2011 ; 13(3): 207-210$

Sgavioli S, Filardi RS, Praes MFFM, Domingues CHF, Andrade PC, Pileggi J, Boleli IC, Junqueira OM. Effect of forced-molting methods and rearing temperatures on the performance and organ biometrics of laying hens. Brazilian Journal of Poultry Science, 2013;15(3):239-245

Schweitzer D, Kimberling G, Spraker T, Sterner FE. Accidental monensin sodium intoxication of feedlot cattle. Journal of the American Veterinary Medical Association, 1984;10:1273-1276. 